\title{
The influence of different overstory removal on planted spruce and several broadleaved tree species: Survival, growth and pine weevil damage during three years
}

\author{
Magnus LÖF ${ }^{a *}$, Robert PAULSSON ${ }^{\mathrm{b}}$, Dan RYDBERG ${ }^{\mathrm{c}}$, Nils Torkel WELANDER ${ }^{\mathrm{a}}$ \\ ${ }^{a}$ Swedish University of Agricultural Sciences, Southern Swedish Forest Research Centre, PO Box 49, 23053 Alnarp, Sweden \\ b PO Domaregatan 7C, 25659 Helsingborg, Sweden \\ ${ }^{\mathrm{c}}$ Regional Forestry Board South Götaland, PO Box 234, 29123 Kristianstad, Sweden
}

(Received 5 February 2004; accepted 7 July 2004)

\begin{abstract}
The influence of different overstory removal on herbivory by the pine weevil to seedlings was studied in a field experiment. Four overstory treatments with middle aged Norway spruce in combination with or without insecticide treatments were applied. Seedlings of the following seven tree species were planted in each of the four blocks: Acer platanoides L., Fagus sylvatica L., Fraxinus excelsior L., Picea abies L. (Karst.), Prunus avium L., Quercus robur L. and Tilia cordata Mill. The seedlings were monitored through the 2001-2003 growing seasons. Highest survival was found among seedlings planted in the overstory treatments with 15 and $20 \%$ light in the understory, whereas best diameter growth in seedlings was found in the clearcut. Overstory trees of Norway spruce decreased herbivory from pine weevil considerably among underplanted seedlings, and the pine weevils fed significantly more on planted Norway spruce seedlings than on all broadleaved tree species. The following rough preference order was obtained: (1) Norway spruce $>>$ (2) beech and oak > (3) ash, cherry, lime and maple. The influence from the insecticide treatment was minor. Therefore, during the conversion of Norway spruce monocultures into mixed species stands using overstories, the use of insecticides against pine weevil is not needed.
\end{abstract}

forest restoration / forest transformation / insect damage / regeneration / shelterwood

Résumé - Influence de différentes suppressions de l'étage dominant sur des plants d'épicéas et de plusieurs espèces de feuillus : survie, croissance et dégâts par le charançon des pins pendant trois ans. L'influence de différentes suppressions de l'étage dominant sur l'herbivorie du charançon des pins sur des jeunes plants a été étudiée dans une expérience sur le terrain. Quatre traitements de l'étage dominant sur des épicéas de Norvège d'âge moyen, combinés ou non avec des traitements insecticides, ont été appliqués. Des jeunes plants des sept espèces d'arbres suivantes ont été plantés dans chacun des quatre blocs: Acer platanoides L., Fagus sylvatica L., Fraxinus excelsior L., Picea abies L. (Karst.), Prunus avium L., Quercus robur L. et Tilia cordata Mill. Les plants ont été suivis durant les saisons de croissance 2001-2003. Le plus haut taux de survie a été trouvé chez les plants plantés dans les traitements de l'étage dominant avec 15 et $20 \%$ de lumière dans le sousétage, alors que la meilleure croissance du diamètre chez les plants a été trouvée dans la coupe à blanc. Les arbres à étage dominant de l'épicéa de Norvège ont diminué considérablement l'herbivorie du charançon des pins au niveau des plants sous-plantés et les charançons des pins se sont significativement plus nourris sur les plants d'épicéas de Norvège que sur toutes les espèces de feuillus. L'ordre de préférence sommaire suivant a été obtenu : (1) épicéa de Norvège >> (2) hêtre et chêne > (3) frêne, cerisier, tilleul et érable. L'influence du traitement insecticide a été mineure. C'est pourquoi, durant la conversion des monocultures d'épicéas de Norvège en groupes d'espèces mixtes utilisant les étages dominants, l'utilisation d'insecticides contre le charançon des pins n'est pas nécessaire.

restauration des forêts / transformation des forêts / dégâts d'insectes / régénération / forêt de protection

\section{INTRODUCTION}

The pine weevil (Hylobius abietis L.) is a major problem for reforestation with seedlings of conifers throughout Europe and Asia $[3,9]$. The widely used silvicultural system in Europe with monocultures of conifers and clear-cutting probably produces optimal breeding conditions for the weevil, since the larvae develop in the stumps and roots of dying and dead coniferous trees [2]. The adult pine weevil feeds on the bark of young seedlings shortly after they have been planted and may cause the death of up to $80 \%$ of coniferous seedlings planted without protective measures following clear-cutting of Norway spruce (Picea abies L. Karst.) and Scots pine (Pinus sylvestris L.) [19, 28].

The use of insecticides (e.g. permethrin) for seedling protection usually keeps seedling mortality at acceptable levels and has therefore been widely used $[9,19]$. However, its use

* Corresponding author: magnus.lof@ess.slu.se 
may become prohibited for environmental reasons, something which may cost e.g. Swedish forestry enormous sums of money in lost growth and failed plantations [32]. Alternative control methods, e.g. a fallow period of two to three years, mechanical site preparation, protective collars, protective stockings and the provision of shelterwood trees, have been proposed but have not prevented all damage $[9,22]$.

Forest restoration has become increasingly common around the globe and the conversion of these anthropogenous coniferous forests, which were planted in Europe from the end of the 18 th century, into natural broad-leaved forests is one type of restoration practice currently being used $[25,26,35]$. It is thus getting more and more common to convert stands through the planting of broadleaves following clear-cutting of conifers or under coniferous shelterwoods [10, 14, 17, 18]. The latter method has advantages compared to clear-cutting through less interference from ground vegetation, less frost damage to planted seedlings and less leakage of nutrients to the ground water [7, 24], although the residual stand at some sites stands a great risk of blowing down [26]. However, little research has been done, which supports forest conversion through the planting of broadleaves under coniferous shelterwoods.

Feeding by the pine weevil on coniferous seedlings has been studied in detail $[2,3,9,27]$. However, pine weevil feeding on broadleaved seedlings is less investigated. Although it is known that adult pine weevils may feed on seedlings of various broadleaved species $[8,12,13,23,30]$, there are almost no quantitative data on the pine weevil's feeding behavior and preferences during forest conversion using coniferous shelterwoods [11]. Knowledge in this area may be important to forest conversion activities, but also in order to find alternatives to the use of insecticides when these may become prohibited.

This study investigated above-ground pine weevil herbivory to seedlings of six different broadleaved species and to Norway spruce planted under different densities of shelterwood trees of Norway spruce. The specific objectives were: (1) to evaluate the influence of different overstory removal on pine weevil feeding behaviour; (2) to examine the effect of permethrin in relation to overstory removal; and (3) to evaluate the feeding preferences and the impact of pine weevils on planted broadleaved and Norway spruce seedlings.

\section{MATERIALS AND METHODS}

\subsection{Study site, climate and experimental design}

The experiment was established in 2001 at a site dominated by Norway spruce in southern Sweden and located near Åkulla, about $20 \mathrm{~km}$ east of Varberg $\left(57^{\circ} 05^{\prime} \mathrm{N}, 13^{\circ} 04^{\prime} \mathrm{E}, 120 \mathrm{~m}\right.$ above sea level). The site is fresh, the soil texture is sandy moraine, and the ground vegetation is a grass type [5]. The site index for Norway spruce, i.e. the dominant height at an age of 100 years, is $32 \mathrm{~m}$ and the Norway spruce forest was 40 years old when the experiment was established.

The 30-year-mean temperature in July and January (climate station located $20 \mathrm{~km}$ west of the experiment) was $16.2{ }^{\circ} \mathrm{C} /-1.3{ }^{\circ} \mathrm{C}$ and the 30 -year-mean annual precipitation was $738 \mathrm{~mm}$ [1]. Compared to the 30 -year mean, the weather was normal from May to September in 2001-2003 with some exceptions. It was warmer than normal in August 2002 and from July to September 2003. There was a lot of pre-
Table I. Stand data and light environments at Åkulla in 2003. The four different overstory treatments are referred to based on their approximate relative light level at $1.5 \mathrm{~m}$ above ground. Mean $\pm \mathrm{SE}$.

\begin{tabular}{lcc}
\hline Overstorey treatment & Stems per hectare & Light, \% of full light \\
\hline L5 & $994 \pm 47$ & $5 \pm 1$ \\
L15 & $538 \pm 24$ & $15 \pm 3$ \\
L20 & $294 \pm 33$ & $20 \pm 3$ \\
L100 & 0 & 100 \\
\hline
\end{tabular}

cipitation in June 2002 and less precipitation than normal in September 2002 and in August and September 2003, respectively [1].

In January 2001, clear-cutting and thinning was done in order to establish the different overstory treatments. The experimental design was randomized blocks with sub-plots (split-split plots). Four blocks were laid out with four overstory treatments in each block. Stand data and light environments in 2003 are presented in Table I. The light levels were approx. 5, 15, 20 and 100 per cent, respectively, of full light. Each overstory treatment was approx. $20 \times 20 \mathrm{~m}$ with a 10 -m buffer zone in each direction. Three blocks were laid out close to each other, whereas the fourth block was laid out approx. $400 \mathrm{~m}$ from the others.

Each overstory treatment and block consisted of two insecticide treatments (sub-plots), each sub-plot including seven rows of different tree species. The insecticide treatments were: No insecticide treatment and insecticide treatment (permethrin). The latter seedlings were treated with insecticide (permethrin, $0.5 \%$ active ingredient) on the lower $10 \mathrm{~cm}$ of the stem in June 2001, 2002 and 2003. The seven tree species were planted in species-separated rows of 20 seedlings in each row (sub sub-plots). Thus, each overstory treatment and block consisted of 14 rows of seedlings. The tree species were ash, beech, lime, Norway spruce, maple, oak and wild cherry (see plant materials below). In May 2001, planting was carried out manually using a planting spade. Planting was done with a distance of $1 \mathrm{~m}$ between seedlings and $1.5 \mathrm{~m}$ between rows. All blocks were fenced against large herbivores.

This long-term experiment was established with two purposes: Firstly, to compare the effect of above-ground herbivory from Pine weevils on early growth and survival in different tree species. Secondly, to compare the long-term effects of different overstory densities on the survival, growth and wood quality in various under-planted tree species. This paper focuses on the influence of pine weevil during the first three years following planting. In order to allow comparisons with other studies, background data on the recolonization of ground vegetation and the diameter growth in seedlings are also reported.

\subsection{Plant materials}

Bare-rooted seedlings of ash (Fraxinus excelsior L.) (2/0) (Billingen, Sweden), beech (Fagus sylvatica L.) (2/0) (Häckeberga, Sweden), lime (Tilia cordata Mill.) (1/1) (Northern Germany), maple (Acer platanoides L.) (2/0) (Poland), Norway spruce (Picea abies L. (Karst.)) (2/0) (Vitebsk Polots, White Russia), oak (Quercus robur L.) $(2 / 2)$ (Poland) and wild cheery (Prunus avium L.) (1/0) (Helsingborg, Sweden) were used. Bare-rooted seedlings were obtained from different nurseries in southern Sweden. Root undercutting at a depth of approx. $15 \mathrm{~cm}$ was done on broadleaved seedlings in the nurseries in the middle of the first growing season.

\subsection{Data collection}

The photosynthetic photon flux density (PPFD) was measured on ten locations per overstory treatment and block (LI-190SA, LiCor Inc., 
NE, USA) above herbaceous vegetation (approx. $1.5 \mathrm{~m}$ ). Measurements were done in two blocks at the end of June and in the two remaining blocks at the end of August, 2003. On each occasion, the sky was clear and the measurements were made between $11.00 \mathrm{~h}$ and $13.00 \mathrm{~h}$.

The seedling diameter at ground level was measured on all living seedlings at the beginning of October in 2001, 2002 and 2003. At the same time, the percentage of vegetation cover was estimated from above the seedlings in $40-\mathrm{cm}$ radius plots close to all seedlings and assigned to one of 11 categories, where $0=0 \%, 1=1-11 \%$, etc., $10=$ 91-100\% vegetation cover. All herbaceous vegetation, naturally regenerated tree seedlings and bushes were included in the estimates, but mosses were not.

Following growth measurements, estimations of above-ground Pine weevil herbivory were done on all living seedlings. The degree of debarking on the seedling stems as caused by the pine weevil was recorded using a scale with 11 levels, where $0=0 \%, 1=1-11 \%$, etc., $10=91-100 \%$ debarking. The whole seedling stem, from ground level to top of seedlings, was used in the estimates. Similar methods have been used in several other studies (e.g. [4, 6, 19, 31]). Old and new herbivory were separated using records of old herbivory and only new herbivory was recorded on each occasion. In order to minimize subjective assessment [4], all visual estimates were done using an elaborate protocol for these measurements. In addition, all visual estimates were done by the same persons, except in 2003.

Other agents of seedling damage than pine weevil, e.g. frost, fungi, waterlogging, browsing from hare and voles, other insects than pine weevil, plant handling and unknown damage, were also observed for each living seedling at each inventory.

\subsection{Calculations and statistical analysis}

The mean frequency of seedlings with feeding scars from pine weevil was calculated for the three years using data from the annual inventories and the number of living seedlings. In addition, the cumulative degree of damage from pine weevil in all living seedlings was calculated in 2003 using the annual inventories.

The general linear model (GLM) procedure for the analysis of variance was used to perform statistical tests on seedling survival, the percentage of seedlings with herbivory from pine weevil and cumulative herbivory following the growing season in 2003 after calculating treatment averages (SAS Institute Inc., Cary, NC, USA). A randomized block design with split-split plots was used. In addition, each insecticide treatment within the different overstory treatments was analyzed using a randomized block design. Before the survival rates and the percentage of seedlings with herbivory were analyzed, frequencies were transformed according to Zar [34] using the formula:

$$
p^{\prime}=1 / 2\left(\arcsin (X /(n+1))^{1 / 2}+\arcsin ((X+1) /(n+1))^{1 / 2}\right)
$$

where $p^{\prime}$ is the transformed frequency, $X$ denotes the number of living seedlings (or number of living seedlings with herbivory) at the end of the experiments, and $n$ is the number of planted seedlings at the beginning of the experiment. Where significant $F$ values occurred, the analysis of variance was followed by Tukey's multiple range test. In the comparisons, $p<0.05$ was considered as significant.

\section{RESULTS}

\subsection{Re-colonization of ground vegetation}

Three growing seasons after planting in 2001, the cover of ground vegetation near the seedlings was about $80 \%$ for the L100 treatment (Fig. 1). In the L20 treatment, the cover of ground vegetation increased from about $20 \%$ in 2001 to $30 \%$

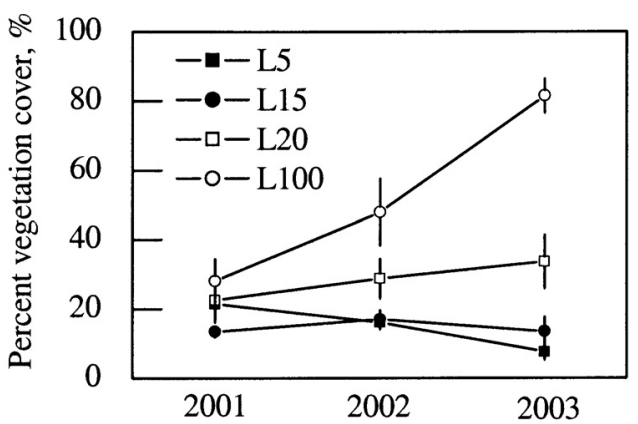

Figure 1. Re-colonization of herbaceous vegetation close to the seedlings at the end of 2001, 2002 and 2003 in four overstory treatments. For a description of treatments, see text. Mean $\pm \mathrm{SE}$.

in 2003. In the L15 and L5 treatments, the cover of ground vegetation did not show a positive development.

\subsection{Survival and growth in seedlings}

After three growing seasons there was higher $(p<0.05)$ survival in the L20 and L15 treatments - ranging from approx. $80 \%$ to $100 \%$ - than in the L100 and L5 treatments (Fig. 2). In addition, there was lower $(p<0.05)$ survival in the L5 treatment than in the L100 treatment. For a majority of the seedlings that died, mortality occurred after the second growing season, except in the L5 treatment where most mortality occurred after the first growing season. No effect of the insecticide treatment was found on seedling survival. In the L100 treatment, there was no difference in seedling survival between tree species when the seedlings were not treated with permethrin. However, when the seedlings were treated with permethrin, ash and maple had lower $(p<0.05)$ survival than beech and cherry. In the L20 and L15 treatments, there was no difference between species when the seedlings were treated with permethrin. However, when the seedlings were not treated with permethrin, maple had lower $(p<0.05)$ survival than lime in the L20 treatment and oak had lower $(p<0.05)$ survival than beech, lime and cherry in the L15 treatment. For both insecticide treatments in the L5 treatment, oak had less than $40 \%$ survival, which was much lower $(p<0.05)$ than in all other tree species except Norway spruce. Here, Norway spruce had lower $(p<0.05)$ survival than beech, lime, ash and cherry when it was not treated with insecticide.

The largest increase in diameter was found in the L100 treatment followed by the L20, L15 and L5 treatments (Fig. 3). In the L100 treatment, beech, oak, lime, cherry and spruce had a higher diameter growth than maple and ash and reached a diameter of between 13 and $20 \mathrm{~mm}$ after three growing seasons. When the experiment was initiated, all tree species had a diameter at ground level of between 5 and $8 \mathrm{~mm}$. There was no tendency for differences in diameter growth between the two insecticide treatments.

\subsection{Damage by the pine weevil}

After three growing seasons, there was a clear effect $(p<0.001)$ of both the overstory treatment and the insecticide treatment on the number of seedlings with feeding scars from 


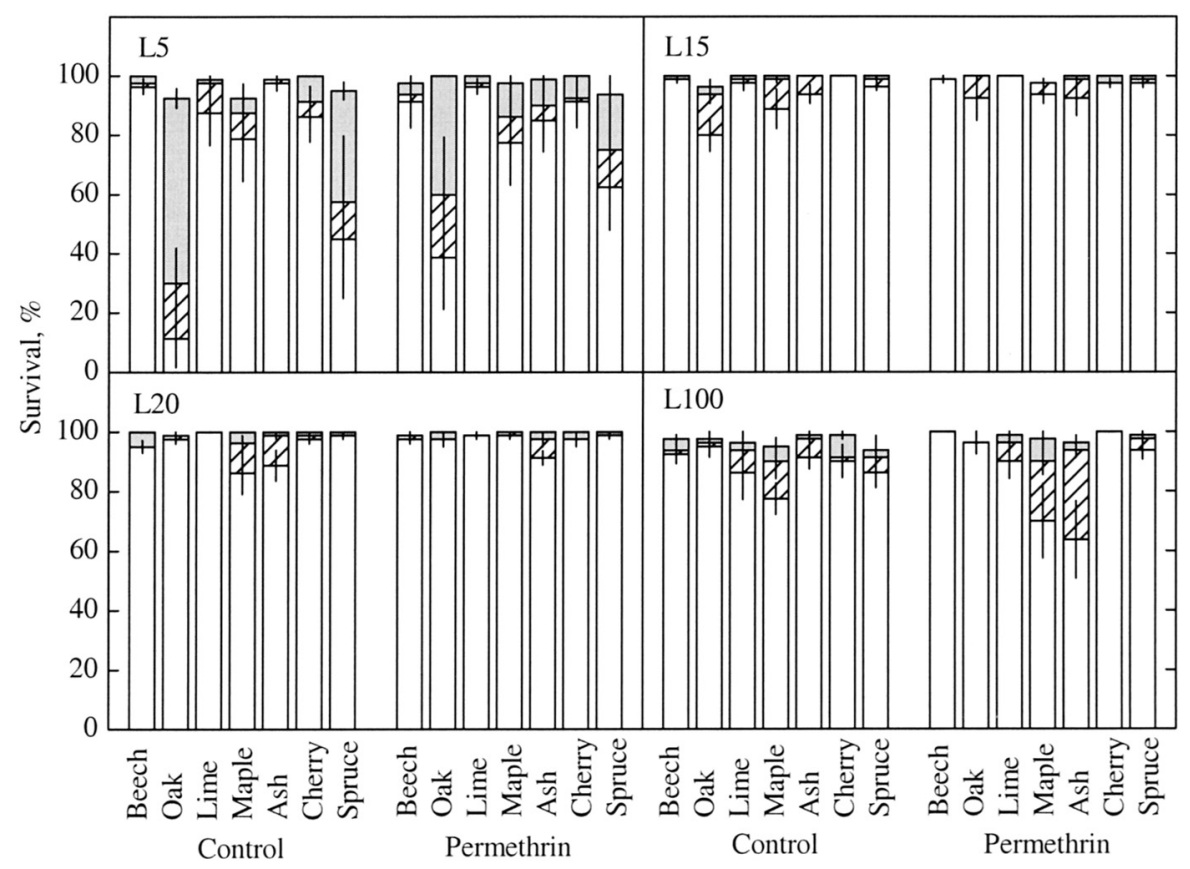

Figure 2. Mean percentage of surviving seedlings in four overstory densities with and without permethrin treatment at the end of the growing seasons in 2001-2003 and following planting in the spring of 2001. For a description of the treatments, see text. 2003 (white), 2002 (pattern) and 2001 (light grey). Mean \pm SE.

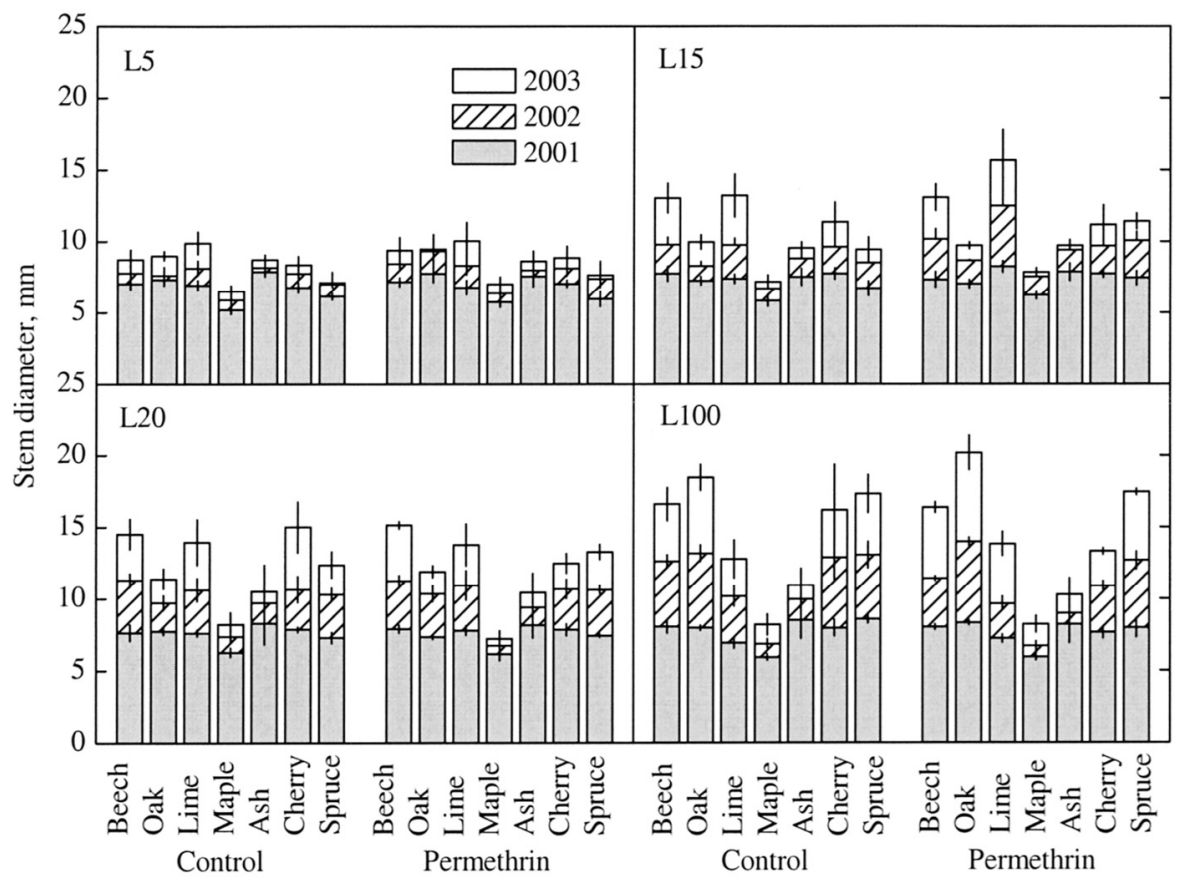

Figure 3. Mean seedling stem diameter at ground level in four overstory densities with and without permethrin treatment in three years. For a description of the treatments, see text. Mean \pm SE.

pine weevil (Fig. 4). However, there was interaction $(p<0.05)$ between overstory and insecticide treatment and permethrin only had a significantly positive effect $(p<0.05)$ in the L20 and
L15 treatments. In both insecticide treatments, the L100 treatment had more $(p<0.05)$ seedlings with feeding scars than the other overstory treatments. The L5 treatment had less $(p<0.05)$ 


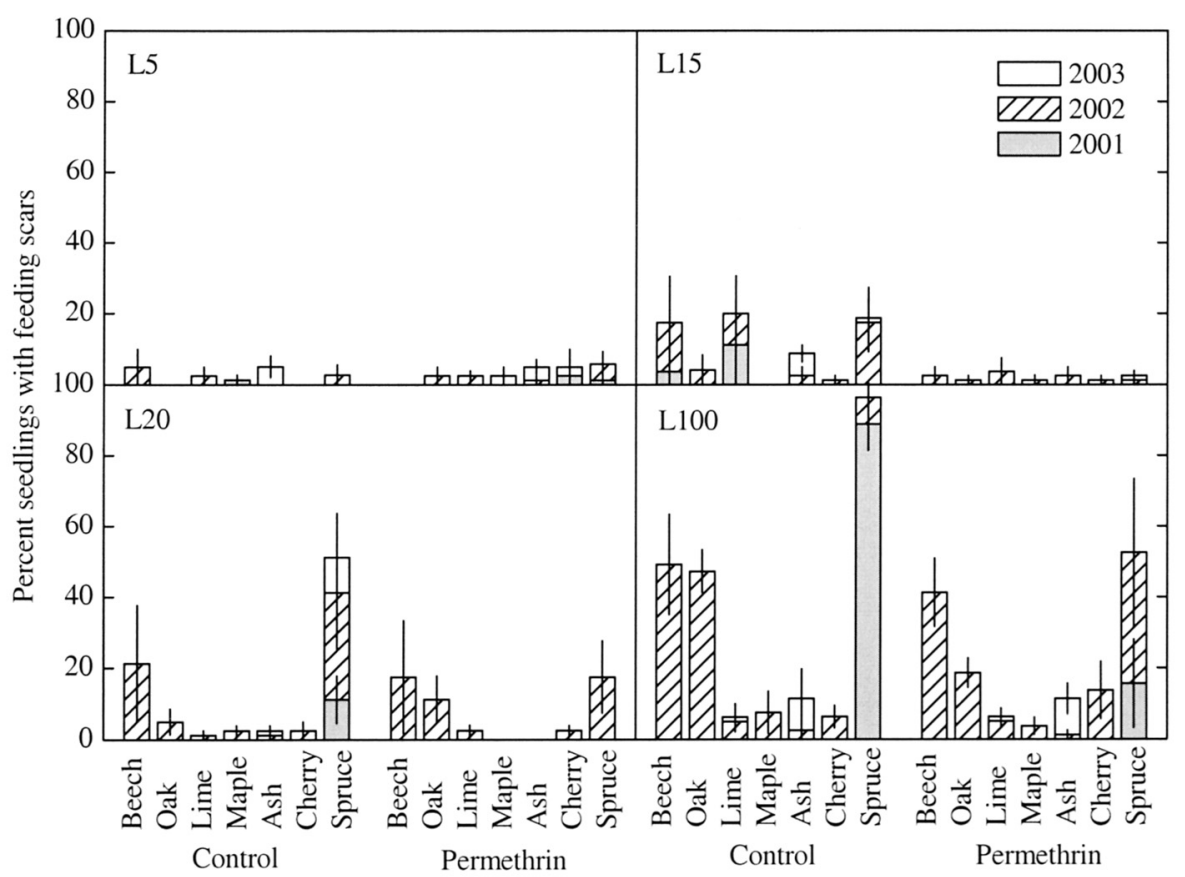

Figure 4. Mean percentage of living seedlings with feeding scars. Seedlings without permethrin treatment (control) and seedlings with permethrin treatment (permethrin). For description of treatments see text.

seedlings with feeding scars than the L20 and L100 treatments. Three years after planting, almost $100 \%$ of the Norway spruce seedlings in the L100 treatment had feeding scars if they had not been treated with permethrin, something which was more $(p<0.05)$ than all other tree species. Here, more $(p<0.05)$ beech and oak seedlings had feeding scars than in other broadleaved species, where few seedlings were touched. Even when treated with permethrin, approx. $50 \%$ of the Norway spruce seedlings had feeding scars in the L100 treatment, and significantly more $(p<0.05)$ than in maple. In the L20 treatment also, approx. $50 \%$ of the Norway spruce seedlings had feeding scars if they had not been treated with permethrin. This was more $(p<0.05)$ than for all broadleaved species except beech. When treated with permethrin, there were no differences between the tree species in the L20 treatment. In the L5 and L15 treatments, there were no differences between tree species concerning the number of seedlings with feeding scars from pine weevil, irrespective of insecticide treatment. A majority of the seedlings were attacked during the second growing season, except for Norway spruce in the L100 treatment, where almost all seedlings were touched already in the first growing season if they were not treated with permethrin.

There was a significant effect $(p<0.001)$ for both overstory treatment and insecticide treatment on cumulative herbivory by the pine weevil after three growing seasons (Fig. 5). However, there was significant interaction $(p<0.01)$ between overstory and insecticide treatment and there was only an effect $(p<0.05)$ of insecticide treatment in the L100 and L20 treatments. For both insecticide treatments, the L100 treatment had higher $(p<0.05)$ cumulative herbivory compared to the L20,
L15 and L5 treatments. In the L100 treatment, there was higher $(p<0.05)$ cumulative herbivory on Norway spruce than on all other tree species when the seedlings were not treated with permethrin, and the values corresponded to about $30 \%$ debarking of the stem over three years. Other species had less than $10 \%$ debarking of the stem. Similar results were found for the L20 treatment, although there was no difference between Norway spruce and beech. There was no difference in cumulative herbivory between tree species when the seedlings were treated with permethrin.

\section{DISCUSSION}

Following three growing seasons and except for the L5 treatment, high seedling survival was found in the present study. Something that shows that high seedling survival in several tree species can be achieved when using planting under shelterwoods of Norway spruce as a tool for forest conversion. For ash and wild cherry, the high survival in L5 treatment was unexpected. According to Lüpke et al. [10], the latter species are grouped together with oak as only slightly shade tolerant. However, low light may cause low growth and high mortality in the long run. Both ash and wild cherry had a tendency of less diameter growth in the various shelterwoods compared to the shade tolerant beech and lime. As expected, diameter growth in seedlings increased with light intensity in the present study.

When the Norway spruce seedlings in the L100 treatment were not treated with permethrin, about $90 \%$ and $95 \%$ of them had feeding scars from pine weevil following the first and second 


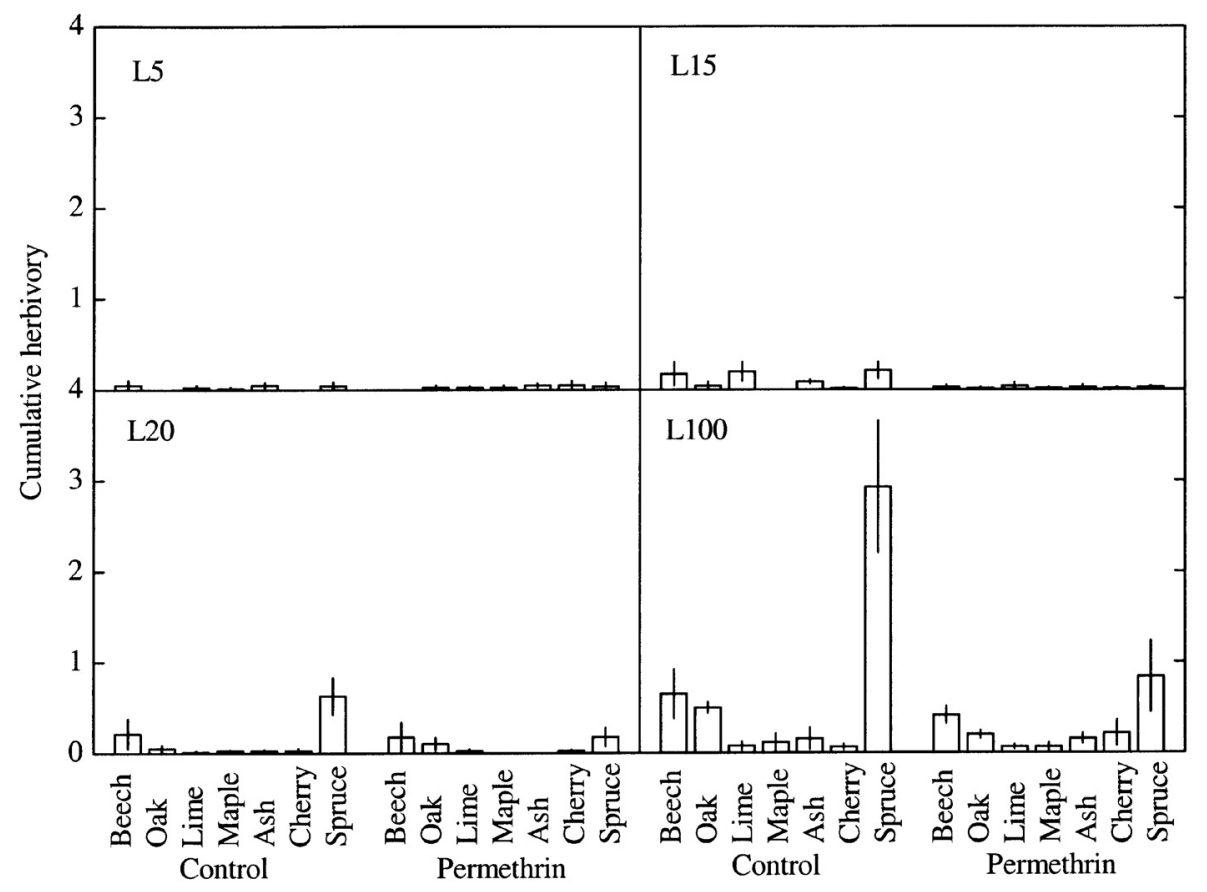

Figure 5. Mean cumulative herbivory by pine weevil in living seedlings after three growing seasons. Seedlings without permethrin treatment (control) and seedlings with permethrin treatment (permethrin). $1=10 \%, 2=20 \%$ and $3=30 \%$ etc. means debarked area of the stem over three years. For description of measurements see text. For a description of the treatments, see text.

growing season, respectively. The attack rate is in line with other studies performed in clear-cuts without site preparation in southern Sweden [28]. After three growing seasons, about $30 \%$ of the stem was debarked on surviving Norway spruce seedlings (3.0 in the ranking system used), something which is also in line with previous research [19].

About $85 \%$ survival was found in Norway spruce seedlings after three growing seasons. This is a higher survival and in contrast with results reported in earlier studies [19, 28]. There is often a positive linear relationship between the number of attacked seedlings and mortality due to pine weevil [4]. However, in the present study, seedlings with relatively large diameter were used. The seedling diameter at ground level in Norway spruce increased from 8 to $17 \mathrm{~mm}$ after the first and third growing season, respectively. Most seedlings of Norway spruce were also attacked during the first growing season. Much higher mortality can be expected when smaller seedlings are used [22, 23]. Similar mortality has been found when large containerized Norway spruce seedlings with a diameter of 8 to $11 \mathrm{~mm}$ were used for planting [31]. Thus, the degree of damage from pine weevil was probably normal during this study.

The present study shows that herbivory by the pine weevil was strongly reduced when overstory trees were present and herbivory decreased with increased overstory density. Similar results have been found by others when using Scots pine as overstory tree [29]. Thus, leaving overstory trees of Norway spruce seems to be an effective silvicultural method in order to protect seedlings from pine weevil damage. However, in line with previous research, all damage was not prevented $[11,22]$.
It has been demonstrated that herbivory from pine weevil will be considerably reduced if the overstory density of Scots pine is greater than $80-160$ stems per ha [29]. In the present study, the density of different overstory treatments ranged from 294 to 994 stems per ha. Thus, the test plots probably had excessive protection from pine weevil. However, it is still necessary to investigate what overstory density of Norway spruce is actually needed for protection.

Various ideas have been put forward to answer the question of why seedlings planted under overstorys show lower levels of damage from pine weevil. Since pine weevil damage normally is more severe in clear-cuts, either larger pine weevil populations or climatic conditions may be responsible. However, resent research has shown that the density of pine weevil populations is the same in shelterwoods as in clear-cuts [15]. Furthermore, there is no correlation between climatic variables such as global radiation or soil temperature and pine weevil damage when experiments have been made close to forest edges [16]. The pine weevil may feed on fresh coniferous twigs, in the crowns of coniferous trees and on living tree roots [9, 20]. Therefore, it is most likely that the overstory trees act as an alternative food source for the pine weevil [16]. It has also been indicated that herbivory from pine weevil increases when the seedlings have contact with the ground vegetation [21]. This is in line with the present study, since the overstory treatments resulted in reduced ground vegetation.

In the present study, there was no effect of insecticide (permethrin) treatments on seedling growth and survival, not even in the L100 treatment where most herbivory from pine weevil 
occurred. This is in contrast with several other studies [11, 19, $22,29]$. Insecticide treatment had a positive effect on the number of seedlings with feeding scars and on cumulative herbivory. However, there was an interaction between overstory treatment and insecticide treatment for the latter variables, something which was probably a result of decreasing herbivory with an increased density of overstory trees. However, the general effect of the insecticide treatment was less effective than in comparable studies $[11,19,22,29]$. In the latter studies, either a more intensive insecticide treatment was used or smaller seedlings. Furthermore, in the present study many tree species were affected by pine weevil to a small extent, irrespective of treatment and this may have masked the effect from the insecticide treatment (see discussion below). In addition, the effect of the permethrin treatment is known to vary greatly between different years [22]. For oak and Norway spruce seedlings in the L5 treatment, a tendency for lower survival was found when seedlings were not treated with insecticide. Besides pine weevils, however, other insect damage from Strophosoma melanogrammum, Otiorhynchus scaber and Hylastes cunicularius was observed. Especially for Norway spruce seedlings, the latter insects made damage in the L5 treatment.

Pine weevil fed much more on Norway spruce seedlings than on broadleaved seedlings. Similar results have been reported earlier, both from laboratory studies and field experiments [8, $11,12,23]$. Differences between tree species were only found in the treatment where no overstory trees were present and in the treatment which resulted in approx. 20\% relative light at seedling level. From these treatments and based on the number of seedlings with feeding scars and the cumulative degree of debarking of the stems, the following rough preference order was obtained: (1) Norway spruce $>>$ (2) beech and oak > (3) ash, cherry, lime and maple. This is in accordance with previous research $[11,12,23]$. Earlier studies have shown that the stem diameter of attacked seedlings influences survival and that fastgrowing seedlings show lower levels of pine weevil damage [31]. Therefore, the preference order depends somewhat on the growth rates in seedlings. In this study, however, the diameter growth of various species was relatively similar, although maple and ash showed less growth in diameter compared to the other species.

In many cases, floral diversity has been shown to reduce pest problems and mixtures of tree species has been advocated as a measure in order to avoid damage [33]. For the establishment of plantations, researchers have discussed the hypothesis that broadleaved seedlings may act as feeding depressants for the pine weevil when coniferous and broadleaved seedlings are planted in mixtures and that it may be an alternative way to control damage [8]. Under laboratory conditions, the latter researchers found less feeding on twigs of Scots pine when the pine weevil also had access to twigs of ash. The results from the present study and from previous experiments [12] do not support this hypothesis. The attack rates and the degree of debarking were normal on Norway spruce seedlings when they were planted in mixtures with various broadleaved seedlings. However, Leather et al. [8] were working with small distances in the laboratory and in the present study the different tree species were not planted closer than $1.5 \mathrm{~m}$ from each other.

The pine weevil is one of the most serious pests of plantations in Europe and several management implications are apparent from this study. Firstly, when seedlings with relatively large diameter are used, seedling mortality due to pine weevil can be kept at an acceptable level. Secondly, overstory trees of Norway spruce will decrease herbivory from pine weevil considerably among underplanted seedlings, and herbivory decreases with increased amounts of overstory trees. Therefore, the use of overstories may be one alternative method to control pine weevil damage. Furthermore, one may also plant broadleaved seedlings instead of coniferous seedlings. Since pine weevil herbivory on broadleaved seedlings was of little importance, the use of costly insecticides then does not seem to be required during forest conversion. Finally, it is not possible to reduce pine weevil herbivory to Norway spruce using broadleaved seedlings by mixing coniferous and broadleaved seedlings.

Acknowledgements: We appreciate the assistance of Per-Olof Erlandsson, Sven Nilsson, Gustav Fredriksson and Gunnar Isacsson from the Regional Forestry Board South Götaland. Our thanks also to Christer Jacobsson and Tove Vollbrecht for their help with field work, and to Nina Eriksson for linguistic improvement. Financial support was received from the Lidellska foundation, the Royal Swedish Academy of Agriculture and Forestry and the Swedish Research Council for Environment, Agricultural Sciences and Spatial Planning.

\section{REFERENCES}

[1] Anonymous, Väder och vatten. Swedish meteorological and hydrological institute (SMHI), Norrköping, Sweden, 2001-2003.

[2] Christiansen E., Gransnutebillens $\varnothing$ kologi og forstlige betydning, Tidsskr. Skogsbr. 79 (1971) 245-262.

[3] Eidmann H.H., Hylobius Schönh, in: Schwenke W. (Ed.), Die Forstschädlinge Mitteleuropas, Vol. 2, Paul Parey, Hamburg, 1974, pp. 275-293.

[4] Eidmann H.H., Lindelöw Å., Estimates and measurements of pine weevil feeding on conifer seedlings: Their relationships and application, Can. J. For. Res. 27 (1997) 1068-1073.

[5] Hägglund B., Lundmark J.-E., Site index estimation by means of site properties, Stud. For. Suec. 138 (1977) 1-38.

[6] Hagner M., Jonsson C., Survival after planting without soil preparation for pine and spruce seedlings protected from Hylobius abietis by physical and chemical shelters, Scand. J. For. Res. 10 (1995) 225-234.

[7] Kazda M., Pichler M., Priority assessment for conversion of Norway spruce forests through introduction of broadleaf species, For. Ecol. Manage. 102 (1998) 245-258.

[8] Leather S.R., Ahmed S.I., Hogan L., Adult feeding preferences of the large pine weevil, Hylobius abietis (Coleoptera: Curculionidae), Eur. J. Entomol. 91 (1994) 385-389.

[9] Leather S.R., Day K.R., Salisbury A.N., The biology and ecology of the large pine weevil, Hylobius abietis (Coleoptera: Curculionidae): a problem of dispersal? Bull. Entomol. Res. 89 (1999) 3-16.

[10] Lüpke von B., Ammer C., Bruciamacchie M., Brunner A., Ceitel J., Collet C., Deuleuze C., Di Placido J., Huss J., Jankovic J., Kantor P., Larsen J.B., Lexer M., Löf M., Longauer R., Madsen P., Modrzynski J., Mosandl R., Pampe A., Pommerening A., Stefancik I., Tesar V., Thompson R., Zientarski J., Silvicultural strategies for conversion, in: Spiecker H., Hansen J., Klimo E., Sterba H., Skovsgaard J.-P., Teuffel von K. (Eds.), Norway spruce conversion - Options and consequences, Research Report EFI 18, S. Brill Academic Publishers, Leiden, Boston, 2004, pp. 121-164. 
[11] Löf M., Influence of patch scarification and insect herbivory on growth and survival in Fagus sylvatica L., Picea abies L. Karst. and Quercus robur L. seedlings following a Norway spruce forest, For. Ecol. Manage. 134 (2000) 111-123.

[12] Löf M., Isacsson G., Rydberg D., Welander N.T., Herbivory by the pine weevil (Hylobius abietis L.) and short-snouted weevils (Strophosoma melanogrammum Forst. and Otiorhynchus scaber L.) during the conversion of a wind-thrown Norway spruce forest into a mixed species plantation, For. Ecol. Manage. 190 (2004) 281290.

[13] Manlove J.D., Styles J., Leather S.R., Feeding of the adults of the large pine weevil, Hylobius abietis (Coleoptera: Curculionidae), Eur. J. Entomol. 94 (1997) 153-156.

[14] Mosandl R., Küssner R., Conversion of pure pine and spruce forests into mixed forests in Eastern Germany: Some aspects of silvicultural strategy, in: Olsthoorn A.F.M., Bartelink H.H., Gardiner J.J., Pretzsch H., Hekhuis H.J., Franc A. (Eds.), Management of mixedspecies forests: Silviculture and economics, IBN scientific contributions 15, Institute for Forestry and Nature Research (IBN-DLO), Wageningen, The Netherlands, 1999, pp. 208-218.

[15] Nordlander G., Bylund H., Örlander G., Wallertz K., Pine weevil population density and damage to coniferous seedlings in a regeneration area with and without shelterwood, Scand. J. For. Res. 18 (2003) 438-448.

[16] Nordlander G., Örlander G., Langwall O., Feeding by the pine weevil Hylobius abietis in relation to sun exposure and distance to forest edges, Agric. For. Entomol. 5 (2003) 191-198.

[17] Otto H.-J., Standörtliche Voraussetzungen, Ziele und Waldbautechnik in Fichten-Buchen-Mischbeständen des Harzes. I, Allg. Forst- u. J. -Ztg. 157 (1986) 188-196.

[18] Otto H.-J., Standörtliche Voraussetzungen, Ziele und Waldbautechnik in Fichten-Buchen-Mischbeständen des Harzes. II, Allg. Forst- u. J. -Ztg. 157 (1986) 214-222.

[19] Örlander G., Nilsson U., Effects of reforestation methods on pine weevil (Hylobius abietis) damage and seedling survival, Scand. J. For. Res. 14 (1999) 341-354.

[20] Örlander G., Nordlander G., Wallertz K., Extra food supply decreases damage by the pine weevil Hylobius abietis, Scand. J. For. Res. 16 (2001) 450-454.

[21] Örlander G., Nordlander G., Effect of field vegetation control on pine weevil (Hylobius abietis) damage to newly planted Norway spruce seedlings, Ann. For. Sci. 60 (2003) 667-671.

[22] Petersson M., Örlander G., Effectiveness of combinations of shelterwood, scarification, and feeding barriers to reduce pine weevil damage, Can. J. For. Res. 33 (2003) 64-73.
[23] Samuelsson F., Damage caused by the pine weevil to deciduous seedlings, Master thesis No. 23, Swedish University of Agricultural Sciences, Southern Swedish Forest Research Center, Alnarp, 2001.

[24] Spellman H., Wagner S., Entscheidungshilfen für die Verjüngungsplanung in Fichtenbeständen zum Voranbau der Buche im Harz, Forst u. Holz 48 (1993) 483-490.

[25] Spiecker H., The growth of Norway spruce within and beyond its natural range, in: Hasenauer H. (Ed.), Ecological and economical impacts of restoration processes in secondary coniferous forests, Proceedings of the international conference on forest ecosystem restoration, 10-12 April 2000, Vienna, Austria, University of Agricultural Sciences, Vienna, 2000, pp. 247-256.

[26] Stanturf J.A., Madsen P., Restoration concepts for temperate and boreal forests of North America and Western Europe, Plant Biosystems 136 (2002) 143-158.

[27] Stoakley J.T., Control of the pine weevil, Hylobius abietis L. and of Hylastes species, Forestry 41 (1968) 182-188.

[28] Sydow von F., Abundance of pine weevils (Hylobius abietis) and damage to conifer seedlings in relation to silvicultural practices, Scand. J. For. Res. 12 (1997) 157-167.

[29] Sydow von F., Örlander G., The influence of shelterwood density on Hylobius abietis (L.) occurrence and feeding on planted conifers, Scand. J. For. Res. 9 (1994) 367-375.

[30] Sylvén H., Snytbaggarna: Studier och fångstförsök, Svenska SkogsvFör. Tidsskr. 25 (1927) 521-551.

[31] Thorsén Å., Mattsson S., Weslien J., Influence of stem diameter on the survival and growth of containerized Norway spruce seedlings attacked by pine weevils (Hylobius spp.), Scand. J. For. Res. 16 (2001) 54-66.

[32] Thuresson T., Samuelsson H., Claesson S., Konsekvenser av ett förbud mot permitrinbehandling av skogsplantor, Meddelande 22003, Skogsstyrelsen, Jönköping, 2003.

[33] Wat A.D., Insect pest population dynamics: Effects of tree species diversity, in: Cannell M.G.R., Malcom D.C., Robertson P.A. (Eds.), The ecology of mixed-species stands of trees, British Ecological Society, Special publication series No. 11, Blackwell Scientific Publications, Oxford, 1992, pp. 267-275.

[34] Zar J.H., Biostatistical analysis, Prentice-Hall Inc., New Jersey, 1984

[35] Zerbe S., Restoration of natural broad-leaved woodland in Central Europe on sites with coniferous forest plantations, For. Ecol. Manage. 167 (2002) 27-42. 